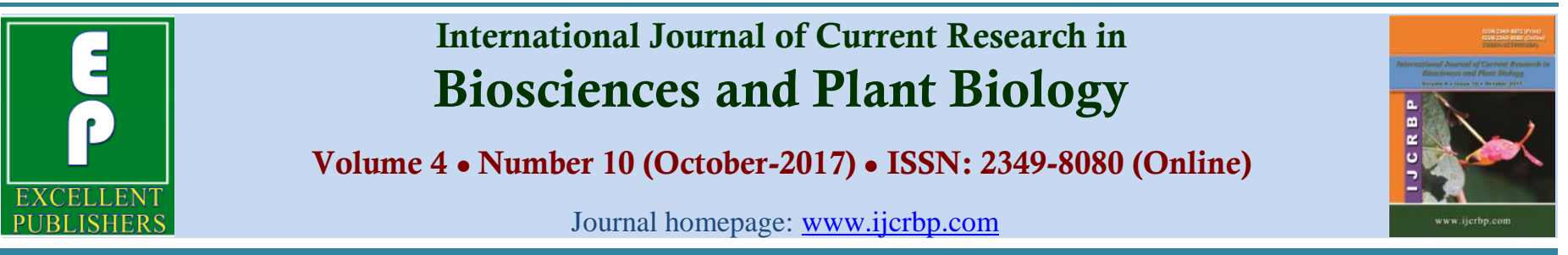

\title{
Some Basidiomycota Macrofungal Species from Salahadin Governorate (North Central Iraq), with the Addition of Four New Species to Iraq
}

\author{
Talib Owaid Al-Khesraji ${ }^{1 *}$, Ahmed Hamed Mahde Shugran ${ }^{1}$ and Razaq Shalan Augul ${ }^{2}$ \\ ${ }^{1}$ Department of Biology, College of Education for Pure Sciences, Tikrit University, Salahadin, Iraq \\ ${ }^{2}$ Department of Entomology and Invertebrate, Iraqi Natural History Museum, Baghdad University, Baghdad, Iraq \\ *Corresponding author.
}

\begin{tabular}{|c|c|}
\hline Abstract & Article Info \\
\hline \multirow{6}{*}{$\begin{array}{l}\text { Between the years } 2016-2017 \text {, a survey on macrofungi was carried out in Al - Alam and } \\
\text { Tikrit provinces from Tikrit district in Salahadin governorate / north central Iraq. It has } \\
\text { been found that the two provinces comprise high diversity of macrofungi. In this paper } 7 \\
\text { basidiomycetous macrofungal species belonging to } 7 \text { genera, } 6 \text { families and } 3 \text { orders were } \\
\text { identified. These species are Coprinellus disseminatus, Ganoderma lucidum, } \\
\text { Lichenomphalia umbellifera, Montagnea arenaria, Phellinus pomaceus, Podaxis } \\
\text { pistillaris and Trametes trogii. All these fungi are described for the first time from } \\
\text { Salahadin Governorate. Out of the seven species, G. lucidum, L. umbellifera, M. arenaria } \\
\text { and P. pomaceus are new addition for the macromycota of Iraq. C. disseminatus and L. } \\
\text { umbellifera are reported rare in the study area. }\end{array}$} & Accepted: 03 October 2017 \\
\hline & ctober 2017 \\
\hline & Keywords \\
\hline & $\begin{array}{l}\text { Agaricales } \\
\text { Hvmenochetales }\end{array}$ \\
\hline & Macrofungi \\
\hline & Polyporales \\
\hline
\end{tabular}

\section{Introduction}

Macrofungi can be defined as fungi that form fruiting bodies greater than $1 \mathrm{~cm}$ in height and / or width (Redhead, 1997; Bates, 2006) and can be further defined as those fungi that produce fruiting bodies visible to naked eye which may be either epigenous or hypogenous (Mueller et al., 2007; Devi and Shrivastava, 2016). Most macrofungi belong to Basidiomycota and Ascomycota (Mueller et al., 2007). Of the 1.5 million estimated fungal species in the world, only $7.3 \%$ (about 110,000 species) are macrofungi, of which only 21,679 species of Ascomycota and Basidiomycota have been described (about 20\% of the estimated macrofungal species) (Mueller et al., 2007). Macrofungi are saprotrophic or mutualistic (mycorrhizal symbionts) but few are plant pathogens (Mueller et al., 2007; Devi and Shrivastava, 2016). Beside of this, macrofungi serve as food, medicine and producers of pharmaceutical active compounds (Redhead, 1997; De Silva et al., 2013; Suliaman et al., 2017).

Salahadin governorate is situated in north central Iraq, north of Baghdad, the capital of Iraq with $24.363 \mathrm{Km}^{2}$ geographical area $\left(34^{0} 27^{\prime} \mathrm{N} 43^{0} 35^{\prime} \mathrm{E}\right)$. This governorate consists of eight districts (Al-Shirkat, Baiji, Tikrit, Al- Daur, Samaraa, Tooz, Balad and Dujail) and its topography varies from foothills in the north eastern parts to desert and steppe in the south west. Salahadin governorate is one of the most rural governorates of Iraq and its arable land comprises $14.715 \mathrm{Km}^{2}$. This governorate is characterized by low levels of 
precipitation with most parts receiving an average annual rainfall of $175-225 \mathrm{~mm}$ while more rain $(250-$ $350 \mathrm{~mm}$ per year) occurs in the north eastern hilly areas. For this, agriculture in this governorate depends heavily on irrigation from Tigris River.

All the eight districts of the governorate are rich in vegetation, comprising tree species (Ex: Populus spp., Salix sp., Pinus sp., and several fruit tree species) with different species of shrubs and herbs. These plants providediverse habitats that sustain different macrofungal species in the governorate. Despite its biogeographic significance, information on macrofungi from thegovernorateis very limited. However, recent surveys on these fungi were reported fromSalahadin governorate (Al-Qaissi, 2014) and other parts of Iraq (Muhsin et al., 2012; Toma et al., 2013; Owaid et al., 2014; Muslat and Owaid, 2015; Al-Khesraji, 2016; Suliaman et al., 2017). This paper reports for the first timeseven Basidiomycota macrofungal species from Salahadin Governorate, four of which new to Iraq.

\section{Materials and methods}

This study was conducted in Tikrit $\left(34^{0} 36^{\prime} 36^{\prime \prime} \mathrm{N} 43^{\circ} 40^{\prime}\right.$ $48^{\prime \prime} \mathrm{E} /$ elevation $137 \mathrm{~m}$ ) and Al-Alam (34 $38^{\prime} 41^{\prime \prime}$ $\mathrm{N} 43^{\circ} 42^{\prime} 0^{\prime \prime} \mathrm{E} /$ elevation $96 \mathrm{~m}$ ) provinces between November 2016 to September 2017. The two provinces as part of Tikrit district are located on the Tigris River, about $140 \mathrm{Km}$ northwest of Baghdad (Fig. 1).

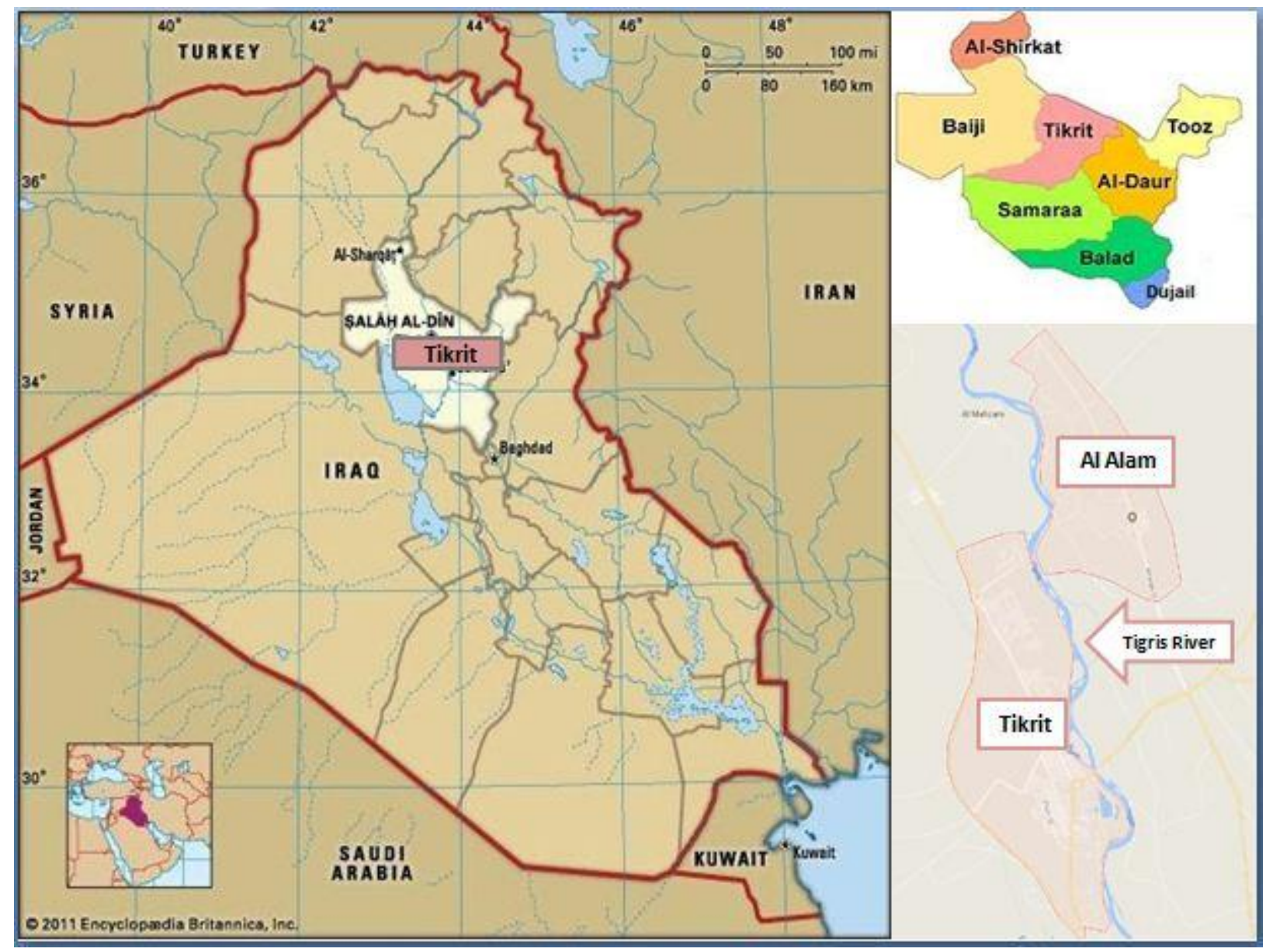

Fig. 1: Maps of the study area.

According to Koppen -Geiger climate classification system, the climate of Tikrit district is classified as hot desert with $22.1^{\circ} \mathrm{C}$ average annual temperature and 182 $\mathrm{mm}$ average rainfall. The least rainfall occurs in June $(0$ $\mathrm{mm}$ ) and the most precipitation falls in December (averages $37 \mathrm{~mm}$ ).
The macrofungi specimens were collected from different sites in Tikrit and Al-Alam provinces, including, orchards, grassland, gardens and desert and wasted areas. Fungal samples were photographed in their natural habitats and in laboratory. Locality, habitat (host/substrate) and habit (solitary, gregarious or other 
growth forms) of the samples with season of fruiting body appearance were recorded. Macroscopic features (including: cap size, shape, color and surface texture, gills color and attachment to stipe (if present), number of pores / mm, stipe size, color, surface texture and presence or absence of annulus and volva) and microscopic features (including: basidium size and its spore number, spore size, shape and color and presence or absence of cystidia with their size, shape and type) were reported. Cotton blue in lactophenol and 3\% $\mathrm{KOH}$ were used for light microscopy. Identification of the samples was performed according to relevant literatures, keys and monographs (May et al., 2003; Kuo, 2004; 2008 and 2017; Gonthier and Nicolotti, 2007; Bhosle et al., 2010; Laursen and Seppelt, 2010; Justo and Hibbett, 2011; Thakur, 2013; Yousaf et al., 2013; Desjardin et al., 2016; Svetlova and Zmitrovich, 2017). All identified samples are deposited in the Department of Biology, College of Education for Pure Sciences /Tikrit University, Iraq.

\section{Results and discussion}

Seven basidiomycetous macrofungal species belonging to 7 genera, 6 families and 3 orders (Coprinellus disseminatus, Ganoderma lucidum, Lichenomphalia umbellifera, Montagnea arenaria, Phellinus pomaceus, Podaxis pistillaris and Trametes trogii) were reported for the first time from Salahadin governorate. G.lucidum, L.umbellifera, M. arenaria and P. pomaceus are new records for the macromycotaof Iraq. Ecologically, the recorded fungal species are either saprobic or parasitic inhabitats.C. disseminatus and $L$. umbellifera are considered rare in study area.Description and distribution of identified macrofungi are given below.

Kingdom : Mycetae

Phylum : Basidiomycota

Class : Agaricomycetes

Order: Agaricales

Family : Psathyrellaceae

Species : Coprinellus disseminatus (Pers.) J.E.Lange

Macroscopic and microscopic features (Fig. 2) : Cap 0.5 $-1 \mathrm{~cm}$ broad, $2-8 \mathrm{~mm}$ tall, conical to bell - shaped, white to pale yellow - brown with brownish disc when young, gray ash in age with brownish disc, minutely granular, lined from the margin to near the disc ; gills free from stipe, white turn blackish in age but not deliquescent in maturity; stipe $1.0-2.5 \mathrm{~cm}$ tall, $1-2$ $\mathrm{mm}$ thick, white, cylindrical, hairy, hallow, often bent from the base. Basidia 18 - 25 × $5-6 \mu \mathrm{m}, 4$ - spored ; spores $7-10 \times 4-5 \mu \mathrm{m}$, elliptic, smooth, with apical pore, deep brown. Habit and habitat : gregarious or in large groups with hundreds of tiny specimens on tree stumps (Populus sp. and Salix sp.) or on decaying wood. Locality : Al - Alam province (Al-Efri village). Season : March - July. This fungus is very rare in study area. On the basis of general morphology, this fungal species was previously reported from $\mathrm{Al}$ - Anbar governorate under the name Coprinus disseminatus (Owaid et al., 2014), so the present study provides for the first time from Iraq a detailed description of this fungus. $C$. disseminatus was also reported from Iran (Karim and Kavosi, 2013), Turkey (Sesli and Denchev, 2014), Tanzania (Tibuhwa et al., 2011) and India (Ao et al., 2016).

Family : Hygrophoraceae

Species : Lichenomphalia umbellifera (L.)Redhead, Lutzoni, Moncalvo \& Vilgalys

Macroscopic and microscopic features (Fig. 3) : Cap : 8 - $12 \mathrm{~mm}$ diam., flat when young, becoming shallowly depressed in the centre, minutely pubescent, slightly striate, cinnamon to brownish, margin, sulcate, crenulate or fluted ; gills broad, decurrent, distant, concolourous with cap ; stipe $10-12 \times 1-2 \mathrm{~mm}$, cylindrical, slightly enlarged at base, concolourous with cap, solid, minutely pubescent. Basidia $4-$ spored, $30-35$ x $8-10 \mu \mathrm{m}$, sterigmata varied in length; spores $8-12$ x $5-7 \mu \mathrm{m}$, elliptical, smooth, hyaline ; clamp - connections and cystidia absent. Habit and habitat : solitary or gregarious, on soil and in association with bryophytes under Thuja sp.. Locality : Tikrit province (Tikrit University campus). Season : December - March. This fungusis very rarely observed in study area. $L$. umbellifera was reported from India (Ao et al., 2016), Czech Republic (Liska et al., 2008), Germany (Stordeur et al., 2015), Poland (Lubek and Jaroszewicz, 2012), Russia (Chesnokova and Konoreva, 2015), Turkey (Sesli and Denchev, 2014) and UK (Graham, 2013).

Family : Agaricaceae

Species : Montagnea arenaria (DC.) Zeller

Macroscopic and microscopic features (Fig.4) : Cap disc shaped 1-3 cm across, convex becoming plane to depressed, disc yellowish brown; gills free, black, not deliquescent at maturity; stipe $3-7 \mathrm{~cm}$ long, $0.5-0.8 \mathrm{~cm}$ thick, cylindrical, often tapering downward, whitish, hallow when young, hard, furrowed and scaly in age ; 
volva thick, $1 \mathrm{~cm}$ high,white, fused with base of stipe but free on top, buried in sand. Basidia 4 - spored ; spores $6-7 \times 3-5 \mu \mathrm{m}$, dark brown, oblong, ovoid, elliptical, thick walled, smooth, with an apical germ pore, black in mass.Habit and habitat : solitary to scattered in sandy and calcareous soils and in wasted places. Locality :Tikrit province (desert and wasted areas near by the university). Season : March - August.
This fungus was reported from Turkey (Sesli and Denchev, 2014), Iran (Ershad, 2009), Qater (Al- Thani, 2010)and Poland (Stasinska and Prajs, 2002).Itwas listed as endangered species in some European countries like Poland (Wojewoda and Lawrynowicz, 1992), Armenia (Nanagulian, 2002), Slovakia (Kautmanova, 2004) and Czech Republic (Holec and Beran, 2006).
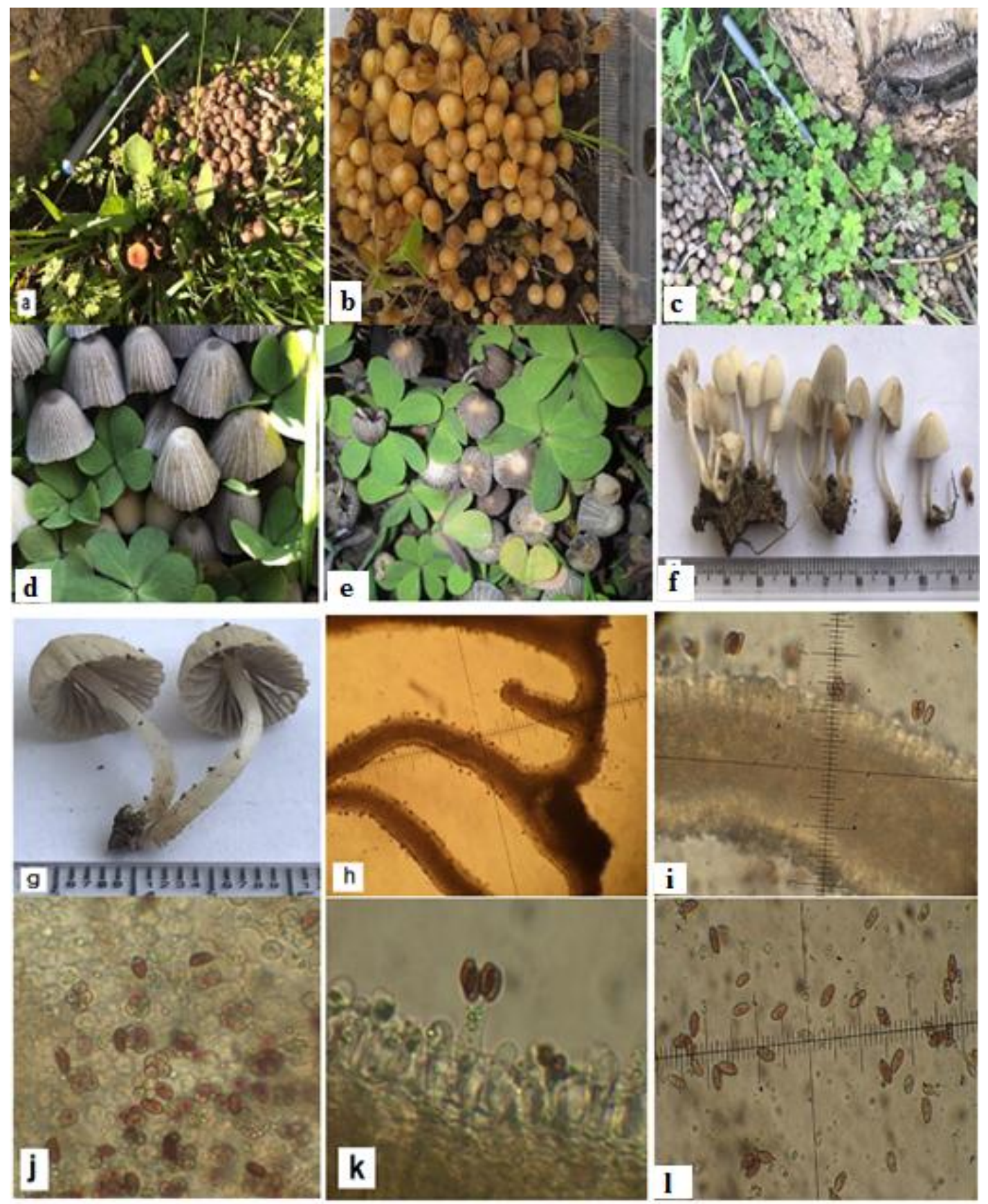

Fig. 2: C. disseminatus. a - e, in natural habitat; a, b, young fruit body; $\mathrm{c}-\mathrm{e}$, mature fruit body; $\mathrm{f}, \mathrm{g}$, general morphology (in lab); h, I, gills in section; j, k, 4 spored basidia in surface view and in section. 1, spores; $\mathrm{h}$ $(100 x) / i-1(400 x)$. 

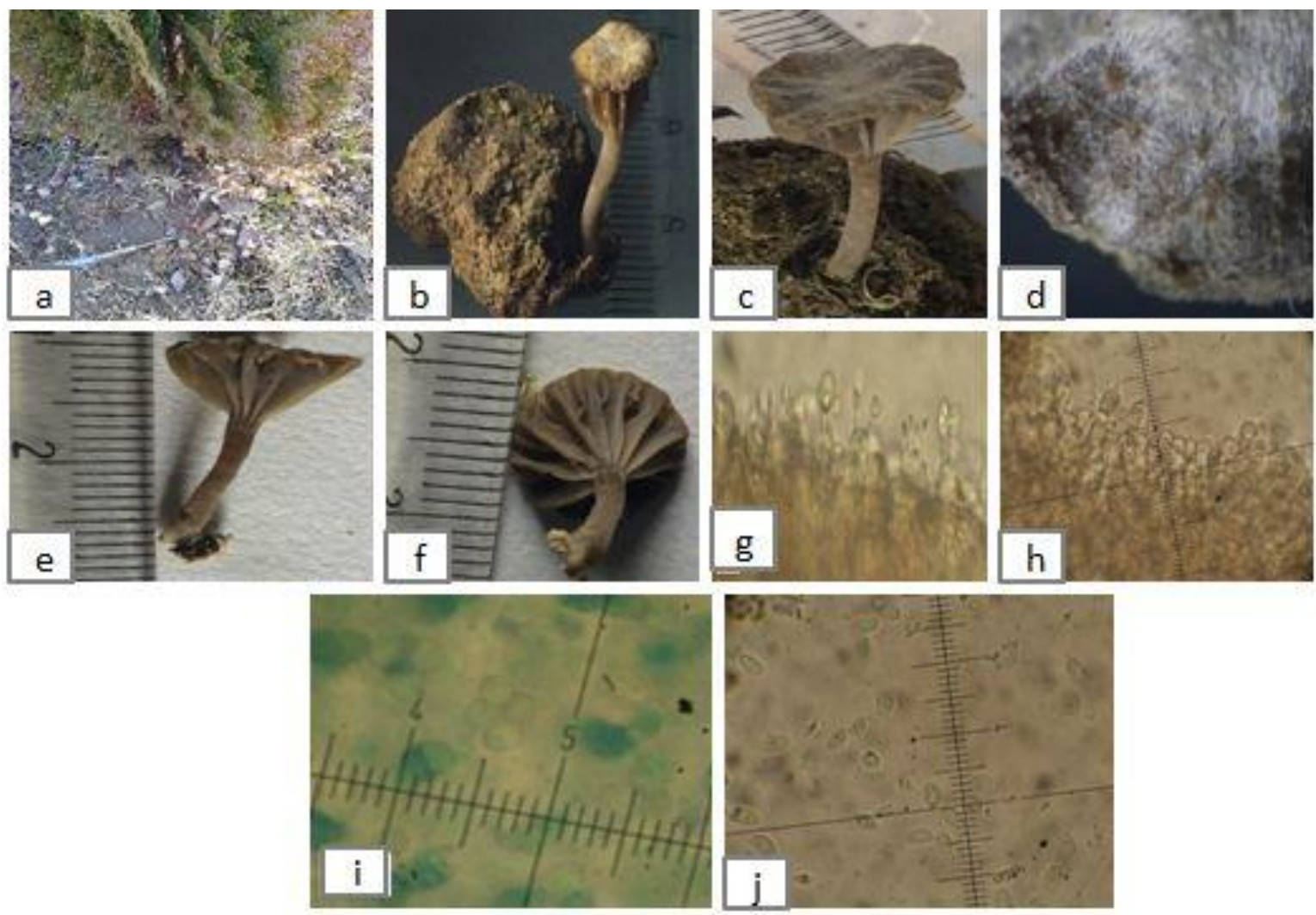

Fig. 3: L. umbellifera. a, in natural habitat (under Thuja plant); b, c, general morphology; d, hairy surface; e, f, stipe, cap and gills; $g-\mathrm{i}$, basidia in section ( $\mathrm{g} \& \mathrm{~h}$ ) and surface view (i); j, spores.
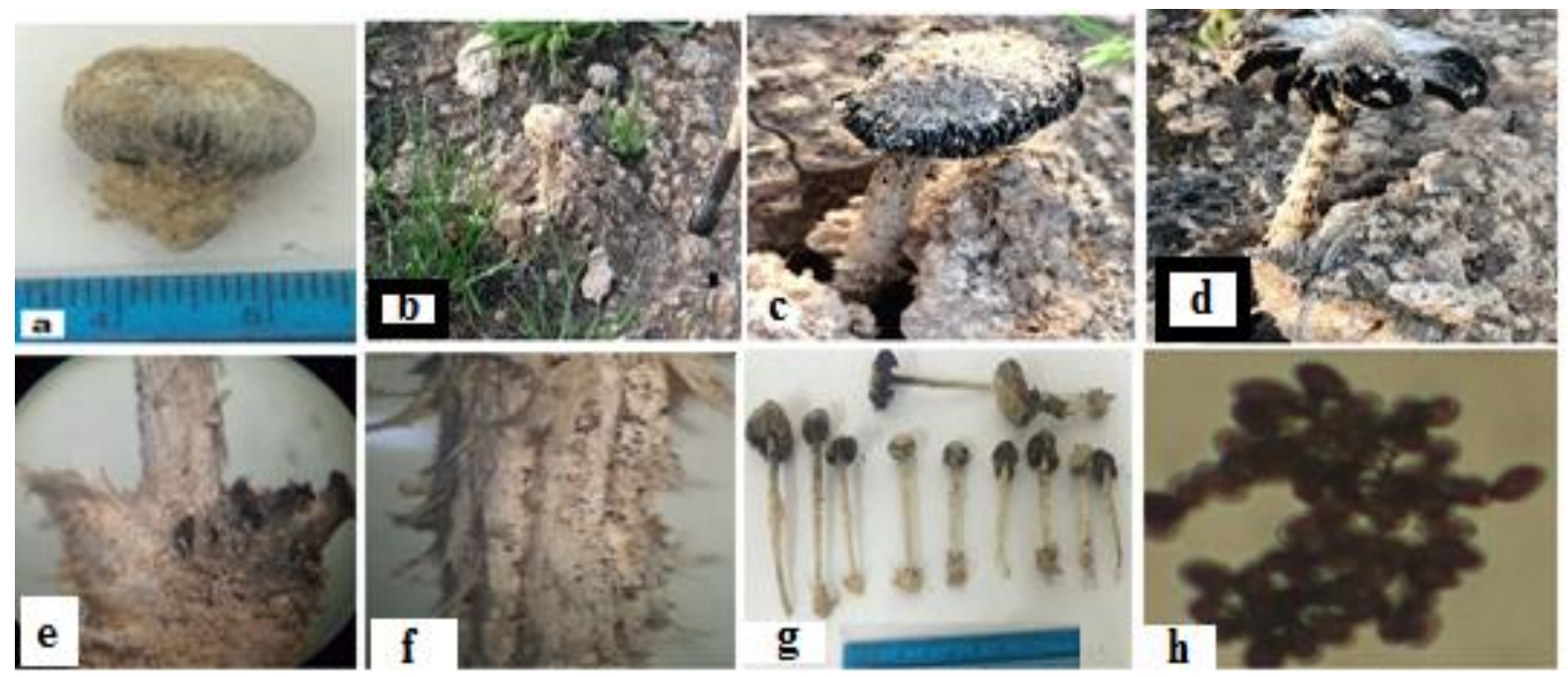

Fig.4: $M$. arenaria. a, in early stages; b - d, in natural habitat; e, volva; f, scaly stipe; g, general morphology; h, spores.

\section{Species : Podaxis pistillaris (L.) Fries}

Macroscopic and microscopic features (Fig. 5) : Cap 6 - $8 \mathrm{~cm}$ tall, 3 - $4 \mathrm{~cm}$ broad, white when young, yellowish brown at maturity, oval to ellipsoidal at maturity, with rounded apex, shaggy to scaly, margin fused to stipe, shredded when mature to release its spore dust; gleba reddish brown in age, capillitial threads non septate, $2.5-5 \mu \mathrm{m}$ broad, interspersed between spores; stipe $9-12 \mathrm{~cm}$ long, up to $1 \mathrm{~cm}$ thick, cylindrical with bulbous base buried in soil, scaly, solid, white to rusty or yellowish brown, ring absent. 
Spores $10.0-16.0 \mathrm{x} 9.0-12.5 \mu \mathrm{m}$ oval, globose to subglobose, smooth, with thick double wall and apical germ pore, when mature reddish in water and ochre colored in $\mathrm{KOH}$, mature spore powder blackish or darck brown. Habit and habitat : solitary or scattered in arid places including desert, semidesert, dunes, roadsides, wastelands and old fields. Locality : Tikrit provinces (Tikrit university campus).Season : April September. This species was reported for the first time from Iraq by Muhsin et al. (2012), to southern Iraq. Here is the first report of $P$. pistillaris from Salahadin governorate /central Iraq.P. pistillaris was reported from some countries bordering Iraqlike Iran (Eckblad, 1976)and Saudia Arabia (Gaafar and El- Wakil, 2015) and from other part in the world like Australia (Lenz and Priest, 1999), India (Rajput et al., 2015) and Brazil (Baseia and Galvao, 2002). It was recorded for the first time from Europe by Friebes and Wendelin (2014).

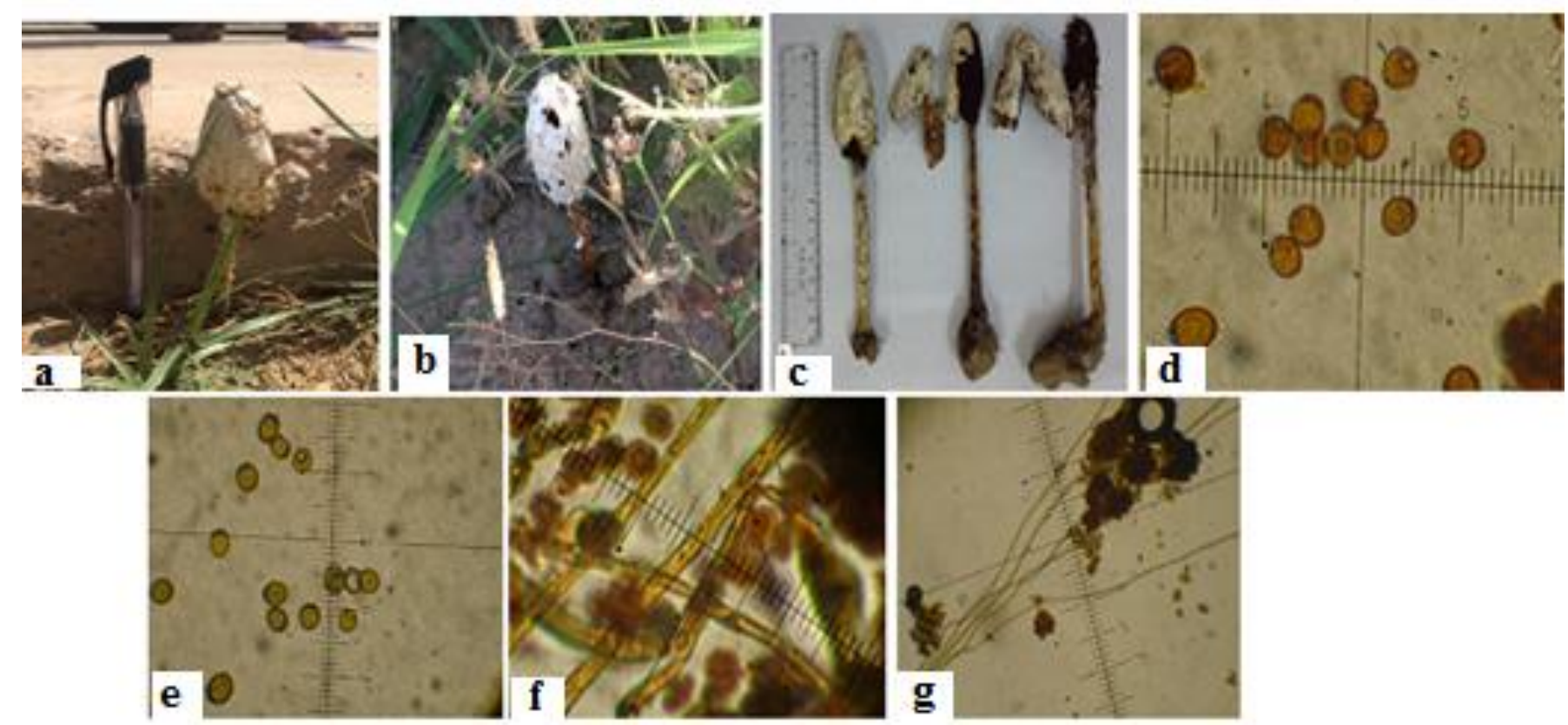

Fig. 5: P. pistillaris. a, b, in natural habitat; e, general morphology; d, e, spores in water and KOH respectively; f, spores and skeletal hyphae; $g$, binding hyphae.

Order : Polyporales

Family: Ganodermataceae

Species : Ganoderma lucidum (Curtis)Karst.

Macroscopic and microscopic features (Fig. 6) : Cap 8 $32 \mathrm{~cm}$ across, $0.5-2.0 \mathrm{~cm}$ thick, knobby when young, fan - shaped or kidney - shaped and very tough in age, shiny red to reddish brown zonate surface, pore surface white but later becoming brownish with $4-5$ rounded pores / mm; stipe : rudimentary but when present, up to $10 \mathrm{~cm}$ tall, broad near the cap and narrow towards the base, concolourous with cap. Spores $7.5-12.5$ x $5.0-$ $7.5 \mu \mathrm{m}$ elliptical to ovoid with one end truncated, double walled, appearing rough under oil immersion. Spore print : reddish brown. Habit and habitat : solitary or gregarious, parasitic on living trees of Prunus domistica and Morus sp. and saprobic on their stumps, usually at or near the base of the tree. Locality : Al- Alam province (villages of AL-Efri, Defsha and Al-Jabara). Season : collected between March - September. This medicinal white rot, wood decaying fungus is cosmopolitan in distribution, particularly in the Far East countries like China, Japan and Korea (Wasser, 2005; Upton et al., 2006). It was also found in India (Thakur, 2013), Turkey (Sesli and Denchev, 2014), Iran (Keypour et al., 2014), USA (Bates, 2006), Colombia (Vasco - Palacios and Franco - Molano, 2013), Qater (Al-Thani, 2010), Italy (Bernicchia, 2001) Cyprus (Torrejon, 2014), Finland (Kunttu et al., 2015).

Family : Polyporaceae

Species : Trametes trogii Berk.

Macroscopic and microscopic features (Fig. 7) : Cap $4-$ $15 \mathrm{~cm}$ across, semi-rounded, flat with concentric zones, frequently overlap in layers to form large fruiting mass, upper surface covered with ocher to brown hairs, lower surface white to creamy ocher, comprises layer of thick 
tubes ended in rounded, angular or irregular pores, $2-3$ pores/ $\mathrm{mm}$, hyphal system trimitic, skeletal hyphae (5 $\mu \mathrm{m}$ wide, cylindrical, thick walled, non - septate, unbranched), second type similar but finner $(2.5 \mu \mathrm{m}$ wide, irregular in contour) and generative hyphae (the thinnest hyphal type, septate), it attaches directly to the wood of dead or living trees. Basidia 4 - spored; spores cylindrical, curved cylindrical or banana -shaped, somewhat granular, $7.5-13.0 \times 2.5-5.0 \mu \mathrm{m}$.Habit and habitat : solitary or gregarious on trunks of poplar and willow. Locality : Al - Alam province (Defsha village).
Season : any season (collected between February September).T. trogii was described for the first time from Northern Iraq (Iraqi Kurdistan) by Suliaman et al. (2017) and this is the first report from central Iraq (Salahadin governorate).This species was reported from other countries like Turkey (Sesli and Denchev, 2014), Iran (Ershad, 2009), Croatia (Zupanic et al., 2009), Spain (Garcia - Bona, 2017), and Russia (Svetlov and Zmitrovich, 2017). T. trogii is rare in western Europe and is listed in Red Book (Svetlov and Zmitrovich, 2017).

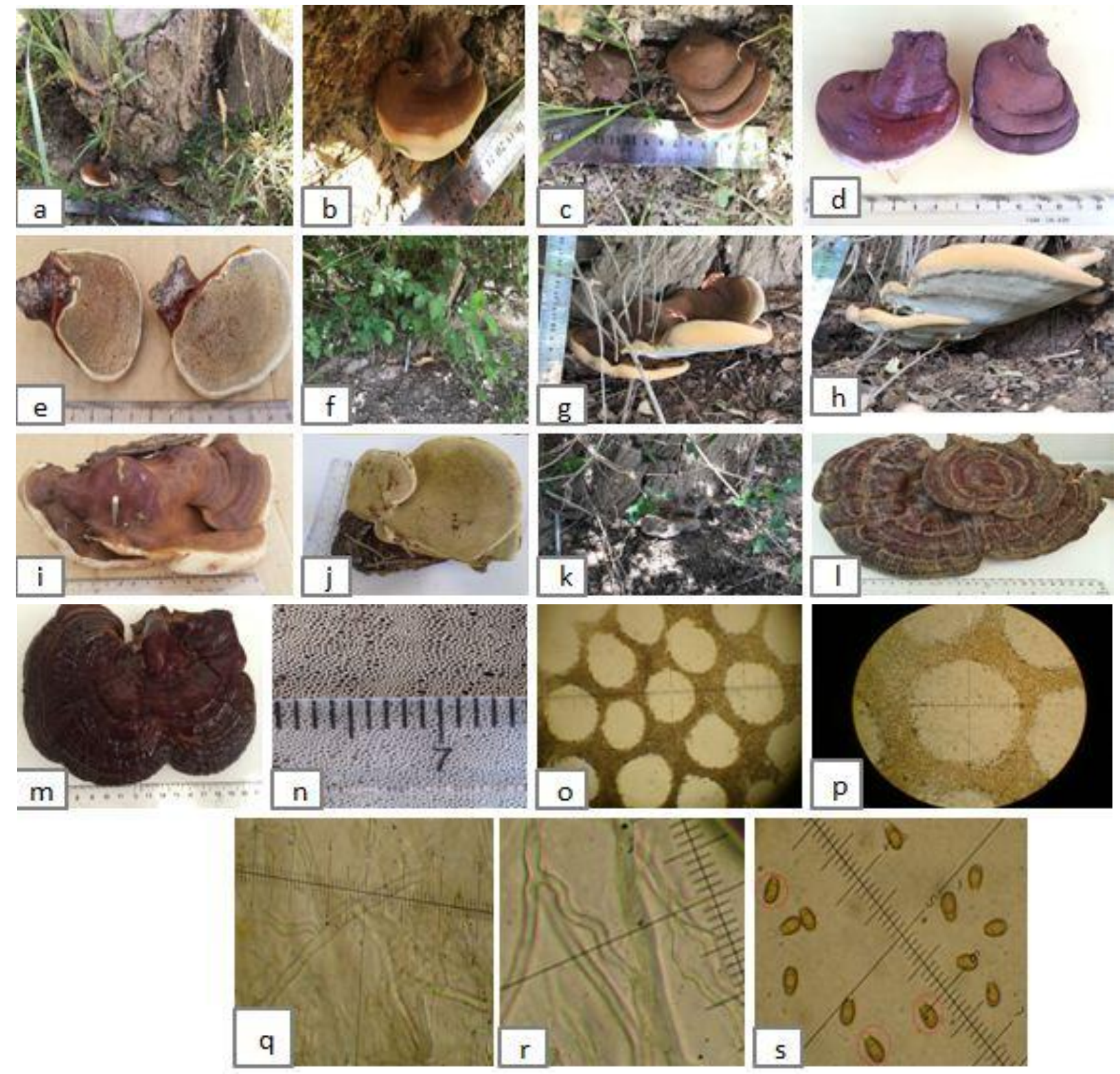

Fig. 6: G. lucidum. a, young stages in natural habitat (under poplar stump); b, c, magnified; d, e, cap upper and lower surface (in lab.); $\mathrm{f}-\mathrm{h}$, advanced stages in natural habitat; $\mathrm{i}$, j, cap upper and lower surface (in lab.); $\mathrm{k}$, mature stage in natural habitat (under Morus sp.); 1, m, general morphology (in lab.); n, lower surface magnified; o, p, pores in section; q, branched skeletal hypha; $\mathrm{r}$, branched binding hypha; s, spores. o-p, 400x. 

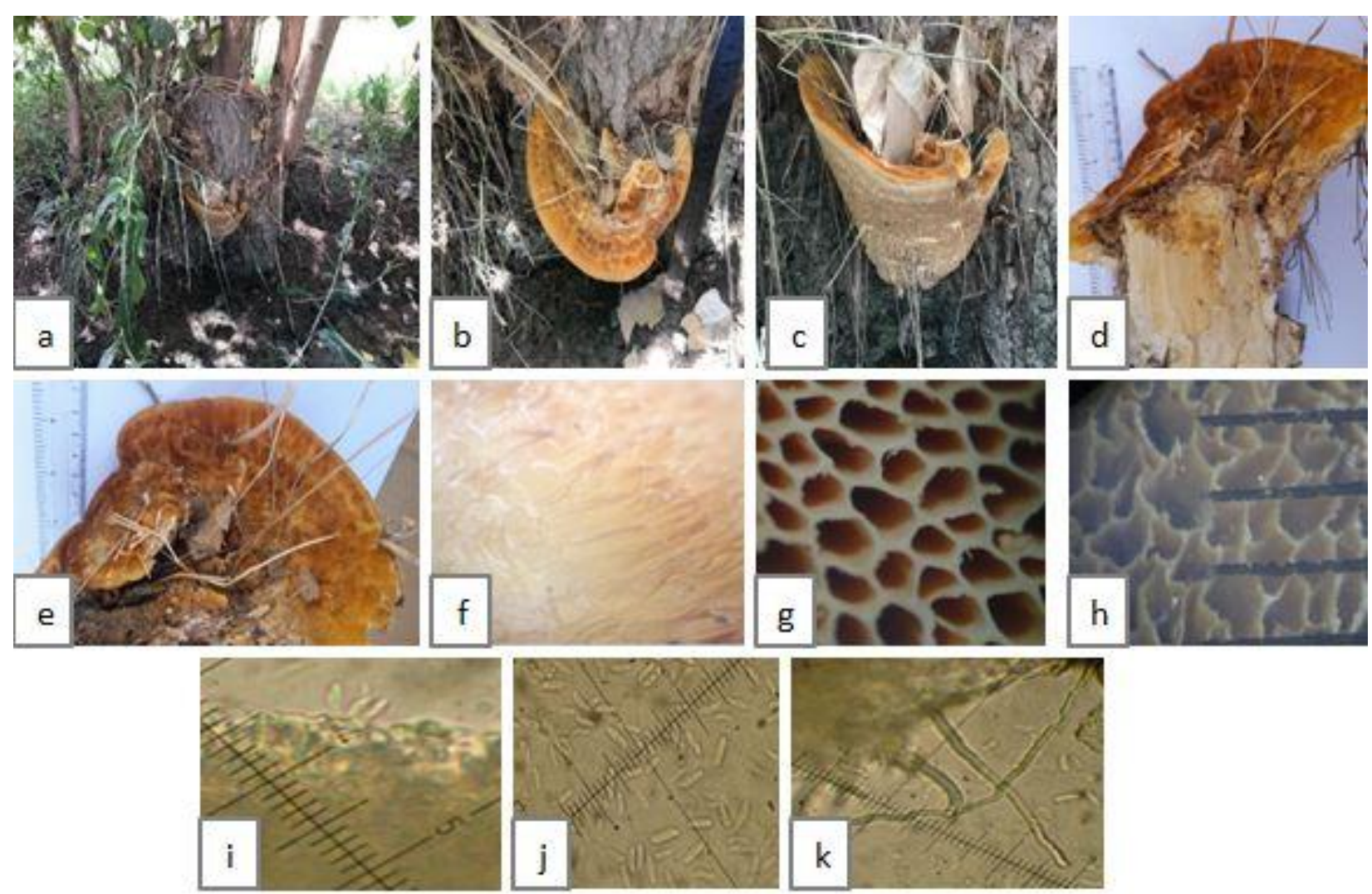

Fig. 7: T. trogii. a - c, in natural habitat; d, e, in lab; f, hairy upper surface; g, h, pores of lower surface; i, basidium; $\mathrm{j}$, spores; k, skeletal and binding hyphae.
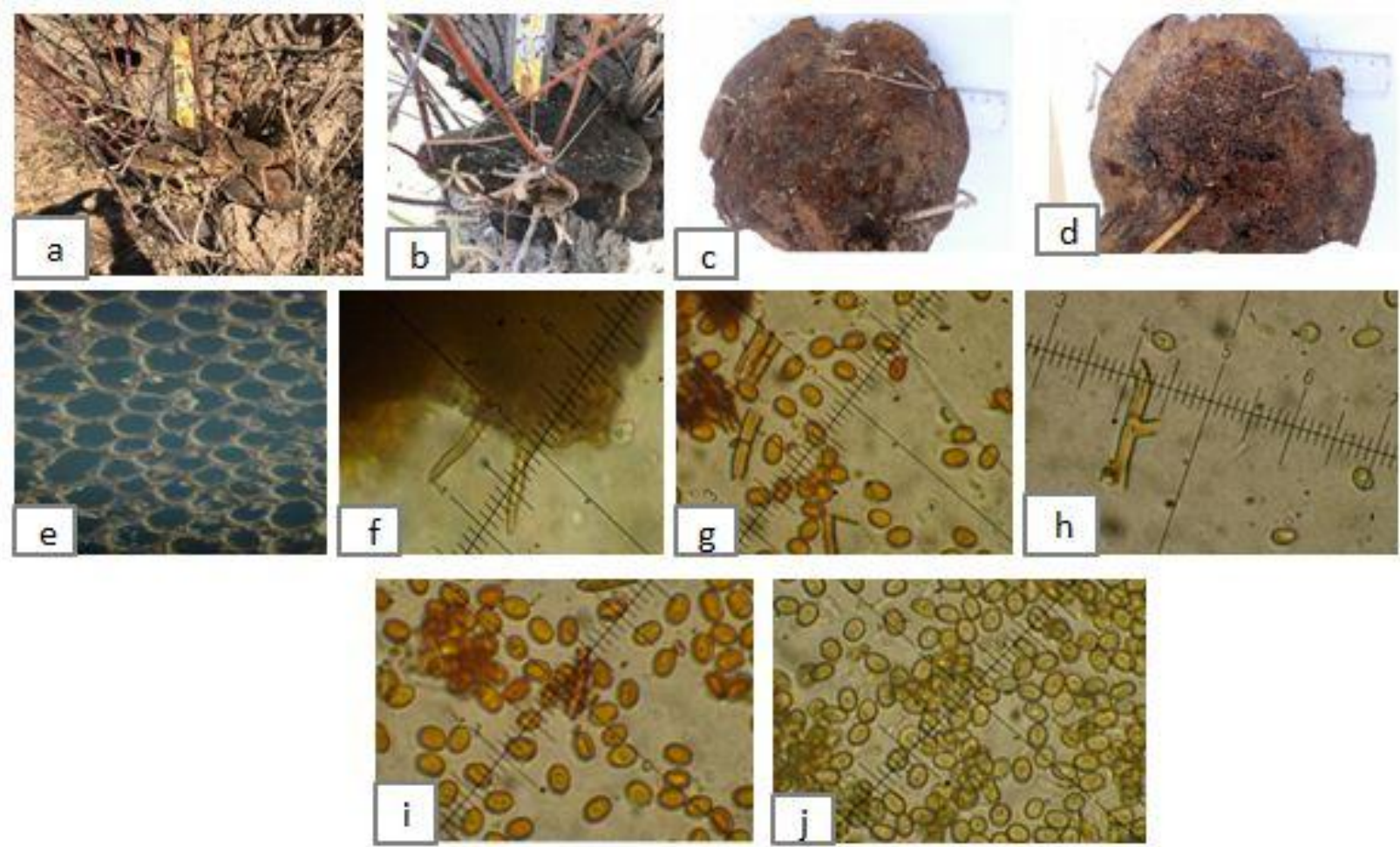

Fig. 8: P. pomaceus. a, b, in natural habitat; c, cap upper surface; d, cap lower surface; e, pores of lower surface; $\mathrm{f}$, setae; g, septate skeletal hyphae and spores; h, branched skeletal hypha; i, spores in water; $\mathrm{j}$, spores in $\mathrm{KOH}$. 
Order : Hymenochaetales

Family : Hymenochaetaceae

Species : Phellinus pomaceus (Pers.) Maire

Macroscopic and microscopic features (Fig. 8): Cap $10-$ $20 \mathrm{~cm}$ across, $5-12 \mathrm{~cm}$ tall, $5-10 \mathrm{~cm}$ height, resupinate, hoof - like, with concentric layers, upper surface grey when young, turning to black brown at maturity, often cracked in age ; tubes yellowish brown or brown, up to $15 \mathrm{~mm}$ deep ; pores very small, rounded, $4-6 / \mathrm{mm}$; trimitic, both generative and sterile hyphae are rarely septate and rarely branched ; spores $7.5-$ $10.0 \times 5.0-6.0 \mu \mathrm{m}$, elliptical to spherical, smooth, hyaline to yellowish, red to reddish brown in $\mathrm{KOH}$, commonly with one oil droplet, flesh brown. Habit and habitat : solitary parasitic or saprobic on trunks and branches of poplar and willow. Locality : Al - Alam province (villages of Defsha, AL-Jabara and Sekhel) . Season : any season (collected between February July). Information on $P$. pomaceus in countries bordering Iraq are only available from Turkey (Sesli and Denchev , 2014). However, the fungus was reported in other parts of the world such as Italy (Bernicchia, 2001), Arizona (Bates, 2006), Bulgaria (Denchev and Assyov, 2010) and Cyprus (Torrejon, 2014).

\section{Conclusion}

This paper reports seven basidiomycetous macrofungal species from Salahadin governorate (Tikrit district), north central Iraq and a contribution was made to Iraqi macromycota by the addition of four new records. The data presented in this study is an important step towards generating a checklist of macrofungi in this governorate in particular and Iraq in general.

\section{Conflict of interest statement}

Authors declare that they have no conflict of interest.

\section{References}

AL-Khesraji, T. O., 2016. Seven new records of ascomycetous macrofungi from Suliamaniya province (Northeast of Iraq). J. Biol. Agric. Health. 6(16), 94-107.

Al- Qaissi, A.R., 2014. A study on the activity of some mushrooms in bioremediation of petroleum wastewater in refineries company- Baji. PhD thesis, Biology Department, College of Education for Pure Sciences, Tikrit University, Iraq.
Al-Thani, R., 2010. Survey of Macrofungi (including Truffles) in Qatar. KBM J. Biol. 1(2), 26-29.

Ao, T., Seb, J., Ajungla, T., Deb, C. R., 2016. Diversity of Wild Mushrooms in Nagaland, India. Open J. For. 6(5), 404-419.

Baseia, I. G., Galvao, T. C. O., 2002. Some interesting Gastromycetes (Basidiomycota) in dry areas from Northeastern Brazil. Acta Bot. Braz. 16(1), 1-8.

Bates, S. T., 2006. A preliminary checklist of Arizona macrofungi. Canotia. 2(2), 47-78.

Bernicchia, A., 2001. A checklist of Corticioid, Polyporoid and Clavarioid fungi (Basidiomycotina) from the Emilia-Romagna region, Italy. Sydowia. 53(1), 1-33.

Bhosle, S., Ranadive, K., Bapat, G., Garad, S., Deshpande, G., Vaidya, J., 2010. Taxonomy and Diversity of Ganoderma from the Western parts of Maharashtra (India). Mycosphere. 1(3), 249-262.

Chesnokova, S., Konoreva, L., 2015. Additions to the lichen biota of SE. Siberia: Records from the Stanovoye Nagor, E highlands (Trans -Baikal region -Russia). Pol. Bot. J. 60(2), 203-216.

De Silva, D. D., Rapior, S., Sudarman, E., 2013. Bioactive metabolites from macrofungi: ethnopharmacology, biological activity and chemistry. Fungal Divers. 62, 1-40.

Denchev, V., Assyov, B., 2010. Checklist of the large basidiomycetes in Bulgaria. Mycotaxon. 111, 279282.

Desjardin, D., Wood, M., Stevens, F., 2016. California Mashrooms Guide. Timber Press, Portland OR. $560 \mathrm{p}$.

Devi, K., Shrivastava, K., 2016. Diversity of macrofungi in 'Jalukbari Reserve Forest' of Kamrup District, Assam. Adv. Appl. Sci. Res. 7(1), 115-119.

Eckblad, F.E., 1976. Contribution to the gasteromycetesflora of Iran. Iran J. Bot. 1, 65-69.

Ershad, D., 2009. Fungi of Iran. Ministry of Jihad - e Agriculture, Agricultural Research, Education and Extension Organization Iranian Research Institute of Plant Protection, Tehran, Iran. 535p.

Friebes, G., Wendelin, I., 2014. Erstnachweis von Podaxis pistillaris in Europa. Zeitschrift für Mykol. 80, 81-92.

Gaafar, A. E., El-Wakil, D., 2015. First record of Podaxis pistillarisis (L.EX Pers.) from Jizan region in Saudi Arabia. Int. J. Curr. Res. 7(2), 1265412657.

Garcia - Bona, L. M., 2017. Guide of Mushrooms and Mushrooms of Navarre. Trametes trogii Berk. Gonthier, P., Nicolotti, G., 2007. A field key to identify 
common wood decay fungal species on standing trees. Arboric. Urban For. 33(6), 410-420.

Graham, F., 2013. Nature in the Dales : 2020 vision YDNPA Fungi survey 2013. Conservation Research and Monitoring Report No. 6, $1-2$.

Holec, J. and Beran, M., 2006. Červený seznam hub (makromycetů) České republiky [Red list of fungi (macromycetes) of the Czech Republic]. Př́roda, 24, pp.1-282.

Justo, A., Hibbett, D., 2011. Phylogenetic classification of Trametes (Basidiomycota, Polyporales) based on five markers dataset. Taxon. 60(6), 1567-1583.

Karim, M., Kavosi, M.R., 2013. New fungal records for Iran mycota from Hyrcanian forests. Middle East J. Sci. Res. 14(5), 729-733.

Kautmanová, I., 2004. Red list species of fungi held in the collections of Slovak national museum - natural history museum (BRA). I. Extinct and critically endangered species. Acta Rer. Natur. Mus. Nat. Slov. L.

Keypour, S., Riahi, H., Borhani, A., Shayan, M.R.A., Safaie, N., 2014. Survey on wood decay fungi Ganoderma species (Ganodermataceae; Polyporales) from Guilan and Mazandaran, Iran. Int. J. Agric. Biosci. 3(3), 132-135.

Kunttu, P., Pennanen, J., Kotiranta, H., 2015. Checklist of aphyllophoroid fungi (Basidiomycota) of the Ekenäs Archipelago National Park, Southern Finland. Biodivers. J. 6(2), 497-504.

Kuo, M., 2004,. Ganoderma lucidum. Retrieved from the MushroomExpert.Com Web site: http://www.mushroomexpert.com/ganoder9ma_luci dum.html

Kuo, M., 2008.Coprinellus disseminatus. Retrieved from the MushroomExpert.com Web site : http://www.mushroomexpert.com/coprinellus _disseminatus.html.

Kuo, M. 2017. Podaxis pistillaris. Retrieved from the MushroomExpert.Com Web site: http://www. mushroomexpert.com/podaxis_pistillaris.html

Laursen, G. A., Seppelt, R. D., 2010. Common Interior Alaska Cryptogams : Fungi, Lichenicolous Fungi, Lichenized Fungi, Slime Molds Fungi, Mosses and Liverworts. University of Alaska Press. 256p.

Lenz, M., Priest, M.J., 1999. The genus Podaxis (Gasteromycetes) in Australia with a description of a new species from termite mounds. Aust. Syst. Bot. 12(1), 109-116.

Liska, J., Palice, Z., Slavikova, S., 2008. Checklist and red list of lichens of the Czech Republic. Preslia. 80(2), 151-182.
Lubek, A., Jaroszewicz, B., 2012. New rare and noteworthy species of lichens and lichenicolous fungi from Bialowieza forest. Polish J. Nat. Sci. 27(3), 275-287.

May, T.W., Milne, J., Shingles, S., Jones, R.H., 2003. Fungi of Australia Volume 2B Catalogue and Bibliography of Australian Fungi 2, Basidiomycota P.P. \& Myxoycota P.P. Melbourne, ABRS / Csiro Publishing, Australia.

Muhsin, T. M., Abass, A. F., Al-Habeeb, E. K., 2012. Podaxis pistillaris (Gasteromycetes) from the desert of southern Iraq, an addition to the known mycota of Iraq. J. Basrah Researches (Sci.). 38(3A), 29-35.

Mueller, G.M., Schmit, J.P., Leacock, P.R., Buyck, B., Cifuentes, J., Desjardin.et al., 2007. Global diversity and distribution of macrofungi. Biodivers. Conserv. $16,37-48$.

Muslat, M., Owaid, M., 2015. Polyporus spp. (Polyporaceae, Basidiomycota) : Rare record from ecosystem of Fallujah, Iraq. Int. J. Environ. 4(3), 185-189.

Nanagulian, S.G., Senn-Irlet, B., 2002. Some Dates about Distribution and Conservation of Threatened Mushrooms in Armenia. Yerevan state University, A.Manouk str.1, 375049 Yerevan, Armenia.

Owaid, M.N., Muslat, M.M., Tan, W.N K., 2014. First collection and identification of wild mushrooms in western Iraq. J. Adv. Lab. Res. Biol. 5(2), 29-34.

Rajput, K. S., Koyani, R.D., Patel, H.R., Vasava, A. M., Patel, R. S., Patel, A. D., and Singh, A. P., 2015. A preliminary checklist of fungi of Gujarat state, India. Cream J. 5(4), 285- 306.

Redhead, S.A., 1997. Macrofungi of British Columbia: requirementsfor inventory. Res. Br. B.C. Min. For., and Wildl. Br., B.C. Min. Environ., Lands, and Parks, Victoria, B.C. Work. Pap. 28.

Sesli, E., Denchev, C., 2014. Checklists of the myxomycetes, larger ascomycetes, and larger basidiomycetes in Turkey. $6^{\text {th }}$ edn. Mycotaxon checklists online (http://www.Mycotaxon. com / resources / checklist / sesli - v 106 - checklist.pdf): pp.1-136.

Stasinska, M., Prajs, B., 2002. New record of Montagnea arenaria (Fungi, Agaricales) and its distribution in Poland. Polish Bot. J. 47(2), 211-213.

Stordeur, R., Cezanne, R., Eichler, M., Henry, D., Kison, H., Schiefelbein, U. et al., 2015. First evidence and remarkable finds of lichen and lichenicolen mushrooms in Saxony-Anhalt and the western part of the national park Harz (lower Saxony). Herzogia. 28, 654-678. 
Suliaman, S.Q., AL-Khesraji, T.O., Hassan, A., 2017. New records of basidiomycetous macrofungi from Kurdistan region- Northern Iraq. Afr. J. Plant Sci. 11(6), 209-219.

Svetlova, T.V., Zmitrovich, I.V., 2017. Polypores and other wood-inhabiting aphyllophoroid fungi. http://mycoweb.narod.ru/fungi/ODG/ODG12.html (in Russian).

Thakur, R., 2013. Studies on genetic variability in Ganoderma lucidum (Curtis) P. Karst for identification of elite strains (Doctoral dissertation, CSK Himachal Pradesh Krishi Vishavavidyalaya, Palampur).

Tibuhwa, D.D., Muchane, M.N., Masiga, C.W., Mugoya, C., Muchai, M., 2011. An inventory of macro- fungi and their diversity in the Serengeti Masai Mara ecosystem, Tanzania and Kenya. J. Biol. Sci. 11, 399-410.

Toma, F.M., Ismael, H.M., Abdulla, N.Q.F., 2013. Survey and identification of mushrooms in Erbil Governorate. Res. J. Environ. Earth Sci. 5(5), 262266.

Torrejon, M., 2014. Annotated checklist of fungi in Cyprus Island. 1. Larger Basidiomycota. Acta Mycol. 49(1), 109-134.

Upton, R., Graff, A., Swisher, D., 2006. Reishi mushroom Ganoderma lucidum, Standarads of analysis, quality control and therapeutics. Am. Herb. 1 Pharmcop. Acopoeia. Post Office Box 66809. Scotts Valley. CA 95067, USA.

Vasco-Palacios, A.M., Franco-Molano, A.E., 2013. Diversity of Colombian macrofungi (Ascomycotabasidiomycota). Mycotoxin. 499, 1-58.

Wasser, S.P., 2005. Reishi or Ling Zhi (Ganoderma lucidum). Encyclopedia of Dietary Supplements. (Eds.: Coates, P.M., Blackman, M. R., Cragg, G. M., Levine, M., Moss, J., White, J.D.). Marcel Dekker, New York. pp.603-622.

Wojewoda, W., Ławrynowicz, 1992. Red list of threatened macrofungi in Poland. In: List of Threatened Plants in Poland (Eds.: Zarzycki, K., Wojewoda, W., Heinrich, Z.). $2^{\text {nd }}$ Edn. W. Szafer Institute of Botany, Polish Academy of Sciences, Kraków. pp.27-56.

Yousaf, N., Khalid, A.N., Niazi, A.R., 2013. Taxonomy of gasteroid fungi from some arid regions of Punjab, Pakistan. J. Biol. Environ. Sci. 3(12), 253-263.

Zupanic, M., Matosevic, D., Pernek, M., Diminc, D., 2009. Lignicolous fungi on pedunculate oak in lowland forests of central Croatia. Period. Biol. 111(4), 397-403.

\section{How to cite this article:}

Al-Khesraji, T. O., Mahde Shugran, A. H., Augul, R. S., 2017. Some Basidiomycota macrofungal species from Salahadin. Int. J. Curr. Res. Biosci. Plant Biol. 4 (10), 74-84. doi: https://doi.org/10.20546/ijcrbp.2017.410.008 